CONJUNCTIONS:

TRANSDISCIPLINARY JOURNAL

OF CULTURAL PARTICIPATION

CONJUNCTIONS, VOL. 7, NO. 2, 2020, ISSN 2246-3755

PEER REVIEWED

RESEARCH

ARTICLE
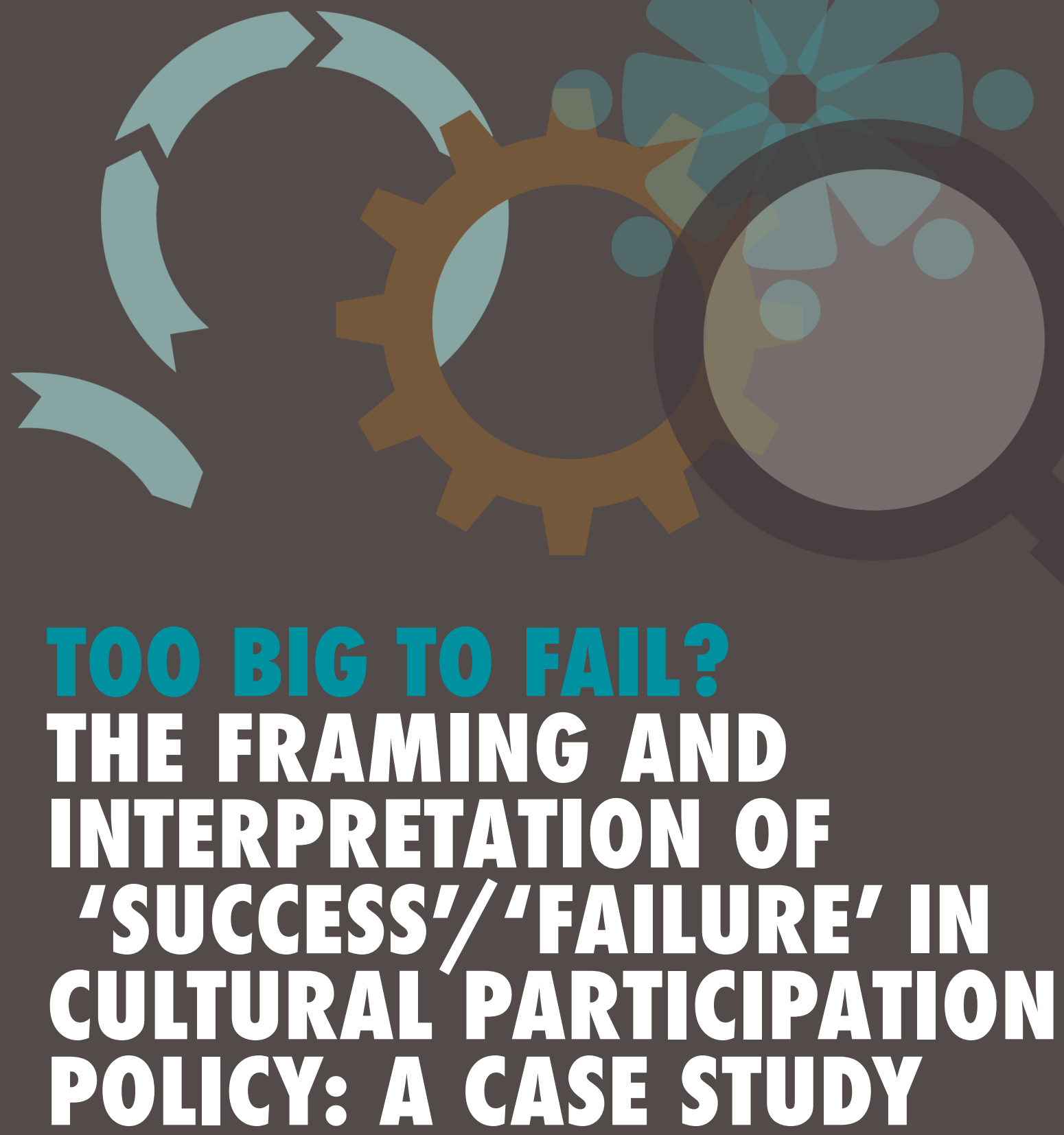

\title{
MARK RMMER
}

CORRESPOWDING AUTHOR: MARK RIMMER, SCHOOL OF ART, MEDIA AND AMERICAN STUDIES, UNIVERSITY OF EAST ANCLIA, NORWICH RESEARCH PARK, NORWICH NR4 TIJ, UK. EMAIL: M.RIMMER@UEA.AC.UK

() 2020. MARK RIMMER. THIS IS AN OPEN ACCESS ARTICLE DISTRIBUIED UNDER THE TERMS OF THE CREATIVE COMMONS ATIRIBUIION-NON COMMERCIAL 3.0 UNPORTED LICENSE (HIIP://CREATIVECOMMONS.ORG/LICENSES/BY-NC/3.0/), PERMIIING ALL NON-COMMERCIAL USE, DISTRIBUTION, AND REPRODUCION IN ANY MEDIUM, PROVIDED IHE ORIGINAL WORK IS PROPERLY CIIED. 


\section{KEYWORDS}

FAIURE, FRAMING, INIERPRETATION, PRESS, IN HARMONY, SISTEMA.

\section{ABSTRACT}

THIS ARTICLE ENGAGES WITH QUESTIONS OF FAILURE IN CULTURAL PARTICIPATION THROUGH A REFLECION UPON MATIERS OF INIERPRETATION AND MEANING. THAT IS, RATHER THAN CONSIDERING THE WAYS OR EXIENT TO WHICH CULTURAL PARTICIPATION PROGRAMMES MIGHT ACHIEVE THEIR STAIED GOALS, THE DISCUSSION CENIRES UPON THE CRUCIAL ROLE OF REPRESENTATIONS AND PERCEPTIONS IN RELATION TO QUESTIONS OF "FAILURE'/SUCCESS". THE DISCUSSION CENTRES UPON ONE CASE STUDY INIIATIVE, ENGLAND'S VERSION OF THE VENEZUELAN EL SISIFMA PROGRAMME, IN HARMONY, AND EMPLOYS FRAME ANALYSIS TO EXPLORE THE WAYS PRESS COVERAGE AND RELEVANI POLICY DOCUMENIS CULTIVATE AN IMAGE OF PROGRAMME 'SUCCESS'. IN ORDER TO HELP REVEAL SOME OF THE PROBLEMATIC ASSUMPTIONS EMBEDDED IN DOMINANT ACCOUNIS, THE ARTICLE ALSO DRAWS ON ORIGINAL INIERVIEW DATA IN EXPLORING THE MARGINALSSED PERSPECIIVES OF PROGRAMME PARTICIPANIS. THE FINDINGS WHICH EMERGE SUGGEST THE NEED FOR PARTICULAR ATIENIION TO THE SYMBOLIC DIMENSIONS OF CULTURAL PARTICIPATION POLICIES IN RELATION TO QUESTIONS OF "FAILUE' / 'SUCCESS".

\section{AUTHOR BIOGRAPHY}

DR MARK RIMMER IS A SENIOR LECTURER IN MEDIA STUDIES AT THE UNIVERSITY OF EAST ANGLA. MUCH OF HIS RESEARCH FOCUSSES ON MUSIC PRACTICES, LISTENING, TASIE AND EDUCATION. THIS WORK ALSO INIERSECTS WIIH INTERESTS IN CULTURAL POLICY, YOUTH PARTICIPATION, COMMUNITY DEVELOPMENT AND COMMUNITY ARTS. RECENTLY PUBLISHED ARTICLES CAN BE FOUND IN CHILDHOOD: A GLOBAL JOURNAL OF CHILD RESEARCH, BRIIISH JOURNAL OF MUSIC EDUCATION AND COMMUNITY DEVELOPMENT JOURWAL. 


\section{Introduction}

Cultural participation might appear, on the face of it, to be an area of policy beset by particular kinds of challenges in relation to questions of failure. The understandable reluctance of those working within the sector to acknowledge a lack of success, together with the problematic nature of much that passes for critical evaluation in the field - as acknowledged within the scholarship on arts advocacy (Gee, 2002, 2004) and evaluation (Belfiore, 2002; Merli, 2002; Selwood, 2002) - would appear to present analysts with challenges in identifying instances of failure. Indeed, not only do the complex and multifarious experiences lying at the heart of cultural participation defy straightforward capture, measurement and comparison (Kaszynska, 2015), but such experiences and their meanings might also be subject to quite varied - and possibly conflicting - understandings of cultural value (Miles \& Gibson, 2016).

Yet cultural participation is, in fact, far from being the only area of policy to face challenges in identifying instances of policy failure. Over recent years public policy scholarship has developed a keen appreciation of the complexity of questions of 'success'/'failure'. Those such as McConnell $(2010,2015)$, for instance, argue the need for analysts to not only bring a nuanced approach to matters of 'fact' but also - in light of the crucial role played by representations and perceptions - attend closely to matters of interpretation and meaning (see also Edelman, 1988; Fischer, 2003). On this basis, McConnell suggests a framework able to account for the ways policies function not only qua 'program' (i.e., in achieving stated goals) but also in terms of 'process' (attaining legitimacy, maintaining support), as well as 'politics' (enhancing a government's reputation). Each of these elements may tilt towards different ends of the 'success' /'failure' spectrum. While a given policy might prove ineffective qua 'program', for instance, it might nonetheless perform well in terms of 'politics' since "responding to popular concerns can become the definition of success" (McConnell, 2010, p. 358). The roles of 'process' and 'politics' therefore alert us to the important symbolic dimensions' of policies and the fact that questions of 'success' /'failure' are as much bound up with the ways they are presented and perceived as their efficacy in achieving specified goals (Bovens \& ' $t$ Hart, 1996).

Drawing upon these ideas, this article takes as its focus the ways different groups frame and interpret 'success'/'failure', as well as considering some of the deeper commitments to which such frames and interpretations appear to relate. In what follows, the focus rests upon one case study initiative, prominent accounts of which appear to have rendered it 'too big to (be seen to) fail': England's In Harmony music initiative. ${ }^{2}$ The adopted approach explores the ways In Harmony has been presented in press articles and policy documents, the propositions and assumptions embedded in such accounts, as well as attending to the "networks of interaction and co-production" (Khan, 2019, p. 537) implicated in their circulation. My analysis also draws upon original interview data to consider how such prominent public accounts compare with the marginalised perspectives of the initiative's young participants. Before further detailing the research approach and empirical materials to be considered, I first offer some background to In Harmony.

\section{About In Harmony}

In Harmony describes itself as "a national programme that aims to inspire and transform the lives of children in deprived communities, using the power and disciplines of ensemble music-making" (ACE, n.d.). It engages primary school children in music learning and playing several times each week. Having launched in 2009 with three pilot projects, it has since grown into a programme partnering schools from six areas of England with lead organisations (comprising either arts/cultural organisations ${ }^{3}$ or local music services, working alongside other bodies ${ }^{4}$ ). Funding for the initiative is provided by Arts Council England (hereafter ACE) and the Department for Education (hereafter DFE), however each of the six projects engages in further fundraising and the charity Sistema England ${ }^{5}$ has adopted a remit to support all Sistema-inspired programmes in England. 'Sistema' refers to El Sistema ('the system'), the Venezuelan initiative upon which In Harmony is based. As with El Sistema, each child participating in In Harmony learns to play a symphony orchestra instrument and the musical repertoire employed is predominantly drawn from the classical Western canon. Learning activities centre on group instrumental and general musicianship sessions led by tutors with classical music learning backgrounds.

The Venezuelan model has come to attract huge interest and support in recent times, with Sistema-inspired projects reaching 
an estimated one million children (Sistema Global, 2015), across more than 60 countries (Creech et al., 2013). Despite beginning in 1975 as little more than a youth music learning initiative, under the stewardship of founder-director José Antonio Abreu (later to become minister of culture), El Sistema rebranded itself in terms of 'social action through music' in the 1990s and was subsequently able, with Hugo Chavez's rise to the presidency, to tap into substantial levels of funding. The programme has since been credited with turning around the lives of hundreds of thousands of poor children.

At some variance with the many adulatory narratives that circulate around El Sistema however, scholarly accounts have noted that its claimed successes suffer from a "lack of support from rigorous, objective research" (Baker, 2014, p. 5). Although numerous evaluations have been commissioned, serious questions have been raised about their reliability, citing methodological weaknesses and misleading conclusions (Baker, 2014). Indeed, independent research has revealed the programme's high dropout rate, its ineffectiveness in targeting the poor and wider failures in achieving claimed outcomes (Alemán et al., 2016). Meanwhile, critical scholarship on both El Sistema and Sistema-inspired initiatives has grown apace in recent years, uncovering problems in relation to pedagogical practices (Dobson, 2016; Fink, 2016), programme philosophies (e.g. Bull, 2016; Logan, 2016) and claims to social justice/inclusion (Mota et al., 2016; Shieh, 2015) amongst wider concerns (see, e.g. Allan et al., 2010; Logan, 2015; Rimmer et al., 2014).

Despite attracting a good deal of critical scholarly attention, however, as Baker notes of El Sistema, "the story of a miraculously successful social programme has gained and retained global currency" (2019, p. 184). For Baker, this can be attributed to both a reluctance to criticise El Sistema within Venezuela and the development of a "global El Sistema industry" (2019, p. 176), comprised of interests from the worlds of classical music and arts education, numerous advocacy and umbrella groups (e.g. 'El Sistema USA', 'Sistema Global'), in addition to an array of sympathetic commentators. This industry has propagated the image of a programme that has not only achieved notable 'social uplift' in Venezuela but also a model whose replication stands to deliver comparable outcomes elsewhere.

\section{Methodological Approach}

The approaches taken in respect of the data explored in this article are twofold. The first, applied to the press articles and policy documents, takes the form of frame analysis, a sub-variant of discourse analysis. In recent times, approaches attentive to the role of discourse in cultural policy have become firmly established (e.g. McGuigan, 2001; Stevenson, 2016, 2019; Waterton, 2010). Initially developed in relation to news media, frame analysis focusses upon the "systems of organized signifying elements" (Pan \& Kosicki, 1993, p. 55) or "interpretive packages" (Gamson \& Modigliani, 1989) employed to give meaning to issues. Packages include a central organising idea (the frame) as well as clusters of framing devices (metaphors, exemplars/ examples, catchphrases, depictions and images) and reasoning devices (which seek to justify policies or responses by proposing causes, consequences and making moral appeals). The functioning of frame packages is also affected by the cultural resonances of their ideas and language, the activities of their sponsors or supporters, and the working practices of journalists (such as their tendency to defer to public officials in their accounts) (Gamson \& Lasch, 1983). Indeed, in light of its attention to the strategic rationality of active agents in their attempts to define reality, frame analysis is especially concerned with the persistent selection and emphasis of some information and the attendant exclusion of that deemed irrelevant (Entman, 1993; Gitlin, 1980; Van Gorp, 2007).

The second approach, adopted in respect of the interviews conducted, corresponds with Yanow's (2000) interpretive policy analysis, insofar as it is centrally concerned with In Harmony participants' understandings of the initiative. Rather than assume that the implications of policy are transparent, this approach proposes that they must be uncovered through an engagement with the experiences, subjective interpretations and meanings of relevant stakeholders. The task of analysis therefore involves identifying the significantly meaningful aspects of initiatives (and their entailments), as well as any points of conflict that reflect different interpretations.

In terms of the samples discussed in what follows, first I consider a corpus of British national and metropolitan press articles and press releases $\left(n=117\right.$ ) from the period June 2008 to January 2020. ${ }^{6}$ Following this, three government policy documents (DfE, 2011 a, 2011 b, 2011 c), issued just before funding responsibility and oversight of In Harmony shifted to ACE in 2012, are 
examined. These offer a policy-oriented reflection upon In Harmony's first few years in operation as well as framing its future trajectory. Finally, in order to facilitate a consideration of how the foregoing accounts might be challenged or disrupted, I turn to consider the key themes emerging from original semi-structured interviews ( $n=111$ ) - aimed at exploring the ways children perceived and understood the value of their In Harmony participation - conducted by research team members ${ }^{7}$ at projects in England (at Telford, Newcastle and Norwich).

In the case of the press coverage and policy documents, data analysis comprised two stages. First, individual articles and policy documents were inductively coded with a view to identifying frame packages, their core signifying elements and relevant reasoning devices. In the second stage, each set of materials was considered holistically to identify patterns of co-occurrences in frame elements. The interviews, meanwhile, were analysed with particular regard for consistencies, patterns or other regularities in terms of the ways children interpreted and saw value in their In Harmony participation.

\section{Analysis 1: British National Press}

Before moving on to consider some of the ways that press coverage framed In Harmony, it is worth briefly outlining its sources and general character. The press commentary on In Harmony is concentrated in articles authored by a handful of writers within the pages of just three 'quality' newspapers: in The Guardian by classical music correspondent Tom Service (ten articles) and chief arts writer Charlotte Higgins (five articles); in The Times by chief culture writer Richard Morrison (four articles) and in The Daily Telegraph by chairman of In Harmony, classical cellist Julian Lloyd Webber (seven articles). Indeed, articles either written by, ${ }^{8}$ or else oriented around interviews with Lloyd Webber account for a good deal of the press coverage. Further feature articles are provided by classical music devotees such as writer, festival director and composer Ivan Hewett (in The Daily Telegraph), Director of Sistema England, Marshall Marcus (in The Guardian) or star conductor and El Sistema product Gustavo Dudamel (in The Sunday Times). Several amongst these commentators boast relevant wider media affiliations, with the BBC's classical music output - across both TV and radio - providing one notable site of overlap. ${ }^{9}$

Turning to the general character of this coverage, as suggested by the extent to which they cited and reaffirmed world-famous conductor Sir Simon Rattle's view of El Sistema as "the future of music for the whole world" (Roberts, 2009), for most press commentators In Harmony appears to have provided a rhetorical platform from which to rejuvenate classical music's image at a time of diminishing cultural relevancy, audiences and funding. Indeed, as the classical music industry scholarship attests, across the contemporary landscape, those who look to "modernise how it is perceived occupy a similar space to those who work each day to market and promote classical music" (Dromey \& Haferkorn, 2018, p. 2). The overwhelmingly positive - indeed wholly uncritical - coverage of In Harmony across the press corpus might therefore be seen as reflective of an interest to validate classical music by positioning it as socially and culturally valuable.

The press corpus also reveals some interesting wider links and relationships, in terms of sources of authority. This is exemplified in the ways that academic scholarship is variously invoked and employed. The detailed scholarship of leading El Sistema researcher Prof Geoffrey Baker, for instance, is mentioned just twice across the whole corpus and only within obituaries of El Sistema founder José Abreu, where its critical nature is framed as both running counter to "the testimony of countless individuals" (Millington, 2018) and irrelevant to In Harmony in any case: "By then, however, the UK version was flourishing..." (The Times, 2018). By contrast, one of the few other academics to feature within the press corpus, Prof Susan Hallam, finds her supportive stance towards In Harmony taken up with some avidity. For instance, although the initiative was barely a year into its existence and lacked any evaluation at the time, in 2010 Hallam advocated that "in this period of austerity ... schools should adopt the In Harmony model" (2010) while elsewhere within the press corpus she is noted as having "consolidated the position" proposed by Lloyd Webber at a music education policy event (White, 2014).

It is perhaps also relevant to note that together with colleagues at University College London Institute of Education - from which El Sistema founder José Abreu received an honorary doctorate in 2012 - Prof Hallam worked on In Harmony's first interim evaluation ${ }^{10}$ (Hallam et al., 2011), subsequently co-authored several reports on the initiative (Hallam \& Burns, 2017, 2018), as well as providing research support to In Harmony Liverpool. One of Hallam's colleagues at UCL was also lead author of the Sistema Global Literature Review (Creech et al., 2013) and her partner - a former government advisor on music education 
and chair of the Music Education Council - is a member of the Sistema England advisory board and staunch supporter of In Harmony (see, e.g. Hallam \& Hanke, 2012). The situation is suggestive of an inner-circle whose influence spans evaluation, research, advocacy and policy. Alongside prominent figures from both the classical music world and arts media then, those comprising the network of sympathetic voices from academia and music education might be considered - by virtue of their noteworthy tendency towards advocacy - as key 'sponsors' (Gamson \& Modigliani, 1989) of the dominant In Harmony package detailed below.

A first signature framing device employed within press accounts seeks, in consistently positioning In Harmony as an 'exemplar' (Gamson \& Lasch, 1983) of El Sistema, to associate the latter's attributes with the former. Indeed, most press articles explicitly connected In Harmony with the Venezuelan programme. In this, commentators followed the lead of then Schools Minister Andrew Adonis when he unveiled In Harmony as "our version of El Sistema" (in Asthana \& Thorpe, 2008). By virtue of this relationship's repetition across press articles, the widely propagated image of El Sistema as a "radical social project" which enables deprived children to "punch through the poverty cycle" (Higgins, 2006), becomes the default position in characterisations of In Harmony.

Interestingly, however, the reasoning devices that are first invoked in support of In Harmony focus less on the social dimensions of El Sistema than its decidedly musical achievements. The anticipated 'consequences' (Gamson \& Lasch, 1983) highlighted in the press coverage issuing in the wake of the 2007 Proms performance by elite youth ensemble, the Simón Bolivar Symphony Orchestra, for instance, seamlessly elide from a concern with musical performance to "lessons...for Britain", curiosity about "how many of our politicians were in the audience" (Pritchard, 2007), and outright advocacy: "One hopes the British government is taking note" (Millington, 2007). Indeed, Adonis' unveiling statement, coming less than a year after that Proms performance, positioned it as a key stimulus to the establishment of In Harmony: "Last August the Simon Bolivar Youth Orchestra played at the Royal Albert Hall. It was stunning, enthralling and inspirational. We want to take this model...and look at how it can be made to work in this country" (in Asthana \& Thorpe, 2008). By conjoining a concern for aesthetic experience ("stunning, enthralling") with aspiration/motivation ("inspirational") in this way, Adonis follows the reviewers in framing excellence in music performance as both ipso facto evidence of El Sistema's 'success' and, by extension, justification for In Harmony. This is, of course, a move which also implicitly invokes a set of discourses bound up with classical music.

Classical music has long been granted a lofty status within Western culture and continues to be associated with notions of transcendent beauty, purity and order (e.g. Johnson, 2002; Scruton, 2007). It was used by the emerging middle classes of eighteenth and nineteenth century England to police class boundaries (e.g. Ehrlich, 1985; Weber, 1975) and when music education was employed in efforts to redeem the morally-suspect working classes in the late nineteenth century (Cox, 1993), classical music learning came to represent a particularly classed morality, bespeaking temperance, respectability and hard work (Bull, 2019). Appeals to high quality performances of classical music - when made to lend weight to claims about social uplift or transformation - therefore draw upon a long discursive legacy (Shiner, 2001; Stevenson et al., 2015).

The framing devices employed in press articles draw from this legacy in several ways. One comes in the form of selected 'depictions' (Gamson \& Lasch, 1983), such as of those who will deliver the initiative's learning activities. The article reporting on Adonis' In Harmony launch announcement, for instance, states that "music teachers, specially selected for their charisma, will then be brought in to teach the children" (Asthana \& Thorpe, 2008), while the government press release also notes the engagement of "charismatic, high quality music teachers" (UK Government, 2008). This appeal to 'charisma' appears designed to evoke the inspirational, transcendent qualities attributed to classical music and its adepts, at the same time pointing towards the role of prestigious arts organisations in facilitating the interface of their 'high quality' musicians with local In Harmony projects. The press corpus' depiction of In Harmony as able to 'instil discipline' also speaks directly to classical music's discursive heritage, revealing the latter's links to the civilising mission long attributed to European high art in the process (Bennett, 1995). While Adonis' launch statement once more sets the precedent here ("Music...teaches discipline and rigour" - in Asthana \& Thorpe, 2008), across subsequent articles commentators both return to this idea (e.g. "children are developing discipline, concentration and focus" - Lloyd Webber, 2011 b), render it relevant to wider concerns (such as "levels of discipline in class" - Shave, 2011) and commend the associated 'hard work' (e.g. Lloyd Webber, 2013; Ritchie, 2009) involved in learning orchestral instruments.

In order to render In Harmony's capacity to discipline and civilise especially appropriate to the members of deprived communities, these are depicted as abject. The repeated drawing of parallels between El Sistema and In Harmony is certainly 
germane in this respect, with the salvationist zeal encouraged towards "outcast children" from "fetid slums and bullet-scarred barrios" (Blackmore, 2007), becoming equally appropriate to Britain's "broken children" (Lloyd Webber, 2009a). A further framing device employed to bolster this depiction is the metaphor of "the family of the orchestra" (UK Government, 2008). Indeed, claims such as those that "the orchestra becomes a second family that will not allow any of them to fail" (Lloyd Webber, 2011 b) appear designed to establish the 'entailment' "ll (Lakoff \& Johnson, 1980) that participating children's families are somehow inadequate or unfit. In a move which goes beyond the disregard for people's cultural interests assumed in deficit models of cultural participation (Miles \& Sullivan, 2012; Stevenson et al., 2015), host communities are also depicted as abject by virtue of their cultural lives, with their members framed as victims of a "post-moral society seeped [sic] in celebrity culture" (Vulliamy, 2010). Indeed, it is precisely by dint of their "spiritual poverty" (Lloyd Webber in Ritchie, 2009), that In Harmony stands to function so effectively as "an antidote to the violent video games and reality TV programmes that pass for entire cultural lives on many estates" (Roberts, 2009).

Correspondingly, the specifically musical lives of participating communities are depicted as distinctly barren. Lloyd Webber is particularly strident in this regard, describing one south London estate targeted by In Harmony as "a musical desert" (in Roberts, 2009), while passionately arguing that all children "should have the right to experience music" (in Cassidy, 2008), and "deserve a chance to discover music" (Lloyd Webber, 2009a). Such statements not only overwrite the varied ways children in these communities already engage with music (Rimmer, 2017), they also betray the narrow way in which 'music' is hereby figured: "music by any of the great composers who have produced some of humanity's finest achievements" (Lloyd Webber, 2015). Other commentators' appeals to "banish the kind of elitism that denies young people the chance to encounter the best of the best" (Higgins, 2009) or "combine an unflinching demand for excellence with a passionate insistence on equality of opportunity" (Hough, 2010) are similarly reflective of a 'democratisation of culture' discourse, long drawn upon by institutions such as ACE and the BBC (Bennett, 1995) and characterised by a commitment to providing access to "the best that has been thought and said" (Arnold, 1869).

The broader package to which the aforementioned devices contribute might be characterised as a 'transformation' frame, of the kind previously noted within cultural policy scholarship (Belfiore, 2011; Stevenson et al., 2015). Indeed, given how official descriptions of In Harmony lay emphasis upon the aim to "transform the lives of children" (ACE, n.d.; Sistema England, n.d.), it is perhaps unsurprising to see this 'catchphrase' (Gamson \& Lasch, 1983) repeated across press accounts. More revealing, however, are the numerous and varied claims that transformation is not only an aim, but an outcome. Within just months of the initiative's commencement, for instance, Lloyd Webber was writing of "the key to In Harmony's success" (Lloyd Webber, 2009b). It is not until the following year, however, that quantitative data begin to appear within press coverage, in claims made by the In Harmony Liverpool director about the percentage of pupils improving "by at least two levels" in both reading (from $36 \%$ to $84 \%$ ) and numeracy (35\% to $75 \%$ ) (in Vulliamy, 2010). However questionable such evidence, ${ }_{1}^{12}$ it nonetheless features across the press corpus from $2011^{13}$ (e.g. Lloyd Webber, 2011 a; The Times, 2018), by which time sympathetic journalists were keen to alert readers to "the government's recognition of In Harmony's 'transformational effect" (Shave, 2011), as noted in a ministerial statement published that year (DfE, 2011 b). The depiction of In Harmony as "impressive" (Dommett, 2011), "highly successful" (Gove, 2012) and conducive to a "transformational effect in schools that have taken part" (Lloyd Webber, 2015) remains prominent across the corpus. Indeed, it's prominence only abates after the publication of an independent, three-year In Harmony evaluation report (Lord et al., 2016), whose conclusions noted no positive effects on participating children's attainment, attendance or wider wellbeing. Despite receiving coverage in one dedicated arts sector magazine (Romer, 2016), these findings are mentioned nowhere in the national press corpus. It can only be speculated how far those findings informed a government press release issued later in 2016, which for the first time described In Harmony less in terms of 'transforming lives' than somewhat more prosaically as "an orchestral training programme...intended to develop positive character traits" (DfE, 2016). 


\section{Analysis 2: Policy documents}

Three documents, each published in the period between the establishment of In Harmony and its expansion in 2012, offer insights into its discursive framing at the level of policy. The first document is a national review of music education in England written by Darren Henley ${ }^{14}$ (DfE, 2011 a), the second is the government response to this (DfE, 2011 b), while the third is a national plan for music education (DfE, 2011c).

Henley's discussion begins in manner akin to many press articles, acknowledging In Harmony's roots in El Sistema and making mention of "the visit to England of the Venezuelan Simon Bolivar Youth Orchestra in 2007" (DFE, 2011 a, p. 21). Following this, the review signals its sponsorship of the aforementioned 'transformation' package, grounding its reasoning in evaluations of the three In Harmony pilot projects (none are cited) which, it is claimed, leave "no doubt that they have delivered life-changing experiences" (DfE, 2011 a, p. 21). Yet while Henley hereby appears to align himself with In Harmony's other sponsors, his review's need to connect - in such "financially straitened times" (DFE, 2011 a, p. 6) - with the austerity agenda imposed by the Conservative-led coalition government of the day means confronting the fact that In Harmony is "an extremely expensive initiative" (DfE, 2011 a, p. 21). This leads to the review's key proposal: a reframing of In Harmony such that "rather than being a pure Music Education project, it should be seen as a high impact social action project" (DfE, 2011 a, p. 21). With musical learning positioned as little more than "an excellent by-product", the review sets the stage for a downgrading of the DfE's responsibility for In Harmony. This proposal is made more explicit several lines later in an "urge [to] Arts Council England" to consider developing "an In Harmony style project" (DfE, 2011 a, pp. 21-22). Indeed, April 2012 would see management and oversight of In Harmony passed to ACE, a body which had, by this time, fully incorporated a concern with "the social impact of the arts and culture" (ACE, 2010, p. 28) into its institutional identity. This move also prefigured wider shifts in music education policy that, through the reduction of direct DFE supervision and the government's broader push towards the 'academisation' 15 of schools, "served to reduce the status of music and the arts in the school curriculum" (Spruce, 2017, p. 720) and facilitate "the 'outsourcing' of music education to music education hubs ${ }^{16}$ and other private providers" (Savage, 2018, p. 111).

Although school music would become increasingly marginalised in England over coming years, a key role is nonetheless envisioned for In Harmony in terms of "a music-led model...for narrowing the gap in attainment...upon which schools could choose to spend their pupil premium funding"17 (DfE, 2011 a, p. 30). That is, given the wider cuts envisioned for the education sector, In Harmony should henceforth be viewed as a specialist intervention appropriate for schools whose pupils' disadvantaged status would render it affordable. In proposing to address a "gap in attainment" by targeting disadvantaged children with a music-led initiative, the civilising power of In Harmony's cultural dimensions (discipline, rigour, excellence, etc.) is once again evoked, albeit somewhat less explicitly than in claims that "there is no social change without the achievement of musical excellence" (Lloyd Webber, 2013).

This document's final word on In Harmony further stresses social-cultural impacts. Having noted that it is "too soon for anyone fully to understand the benefits that they [projects] might be bringing to the communities" (DfE, 2011 a, p. 30), Henley goes on to observe how regrettable it would be if the initiative were to end before "our fully understanding its potential as a tool for inner-city urban regeneration and as a means of delivering long-term cost savings to the public purse as an agent of community change" (DfE, 2011 a, p. 30). Such lack of full understanding only serves to highlight the extent of overlexicalization ${ }^{18}$ at work, as considerable rhetorical effort is employed in proposing reasoning devices based on both economic ("regeneration", "cost-savings", "public purse") and moral/cultural claims ("community change").

The government response to Henley's review (DfE, 2011 b) largely recapitulates the latter's repositioning of In Harmony in terms of 'social action'. Indeed, despite noting In Harmony's "early indications of success", ministers Gove and Vaizey nonetheless proceed, in their prefatory statement, to acknowledge that they "have a clearer idea now of what constitutes a programme that can truly make a difference" (DfE, 2011 b, p. 3), by which is meant an intention to "transform In Harmony from a good music experience into a regeneration programme" (DFE, 2011 b, p. 9). Readers go on to learn that $£ 500 k$ will be allocated to the existing projects over 2011-2012 and that it will be for ACE to decide "whether to fund the programme in the future" (DFE, 2011 b, p. 9).

The way In Harmony is framed in the national music education plan published later in 2011 suggests - in line with Henley's review and the government response to it - that it is to be understood as a tool for addressing the moral and cultural failings of 
its target population. The plan's customary mention of El Sistema, for instance, describes its success less in musical terms than in "steering young people away from drugs and crime" (DfE, 2011 c, p. 19). Introducing In Harmony as a programme "enabling children from areas of exceptional deprivation to...have a positive impact on their communities" (DfE, 2011 c, p. 7) also furnishes a frame oriented around the prevention of what might otherwise be 'negative' impacts. Once again, "narrowing the gap" is the claimed objective, although the elaboration of what this now means brings deficits in children's personal qualities ('attitude', 'aspiration', 'behaviour') to the fore, while the subsequent quotation from a school inspection report highlights action at the level of "the self-esteem and pride of pupils and their parents and carers" (DFE, 2011c, p. 20). To this end, and in spite of the aforementioned austerity agenda, the plan announces that In Harmony will be expanded and funding increased, while "projects may also be able to draw on charitable/business support or on Lottery funds" (DfE, 2011 c, p. 20). All this comes, however, within the context of projects ultimately becoming "self-sustaining" and reducing their "exclusive dependence on central government support" (DfE, 2011c, p. 20).

\section{Analysis 3: Child participants}

While the importance of incorporating children's perspectives into activities and initiatives involving them is well-established (e.g. Badham \& Wade, 2005; DCSF, 2008; Local Government Group, 2011), questions of youth agency take on particular importance in the case of child-focussed "facilitated participation" programmes ${ }^{19}$ (Gibson \& Edwards, 2016). Sistema-inspired initiatives have, however, come in for criticism for their "lack of interest in children's autonomy and creative powers" (Dobson, 2016, p. 106). By attending to participants' responses to In Harmony, the following discussion highlights the salience of questions of autonomy, as well as attending to the wider sets of concerns detailed within children's accounts.

One aspect of children's participation to emerge quite clearly - and one that appeared to bring wider implications for the ways In Harmony was interpreted and understood - concerned its obligatory nature. In the following interview excerpts, for example, rather than simply describing what they did as participants, children spoke (in response to a question about what In Harmony participation involved) of what - by virtue of the initiative's 'whole-class' approach - they had to do:

They [i.e., music tutors] come in and get violins out and... when * music tutor name* asks us to play we do, when he tells us to stand up we do and when he asks us to sing we do.

(Girl, age 8)

Miss [i.e., the teacher] says practice makes perfect and violin is different to music because you have to do it, you have to do it...[pause]... because you have to do it. (Girl, age 7)

We have to play whatever the conductor tells us to play.

(Boy, age 10)

Indeed, In Harmony's obligatory nature led many children to draw comparisons between its activities and those of other mandated school lessons. By contrast, the aspect of In Harmony that was generally viewed more favourably by its young participants concerned what - by virtue of sometimes being permitted to take musical instruments home - children got to do:

[I like] practising on my own because [I] can practice all day and you get to play your own tunes.

(Girl, age 9) 
Researcher: So what do you enjoy about it [playing an instrument]?

Child: $\quad$ Because I get to take it home...show Mum and Dad and sister.

(Girl, age 8)

Researcher: Why do you enjoy playing [music]?

Child: $\quad$ Because I get to take my cello home... just want my Mum and

Dad and sister to see.

(Boy, age 6)

Whereas dominant press and policy accounts framed the 'discipline' imposed though In Harmony's music learning practices as central to its promise of social uplift, children's accounts revealed not only how these obligatory aspects of the project were largely unwelcome but also that when children were interested to pursue instrument learning, this was often sustained by instances of autonomous musical practice. Indeed, as the last two interview excerpts presented above suggest, the satisfaction derived from these activities was not simply a matter of the 'intrinsic' value of self-determined instrument playing. Rather, conspicuously interwoven into the accounts of the minority of children who found enjoyment and value in their In Harmony instrument learning/playing was a sense of validation from significant others and especially family members:

It's really fun playing at home because Mum and Dad and relatives get to listen to you and get to praise you and they tell you if you're doing good.

(Girl, age 11)

They [parents] find it quite fascinating...they want me to be in an orchestra in front of loads of people.

(Boy, age 7)

Correspondingly, where family validation was not forthcoming (as was the case for many), children were less likely to perceive value in their In Harmony participation:

Child: I just find it's kind of boring, cos you're just blowing on it and it's a piece of brass and I just, I just think it's boring...

Researcher: Do you take your instrument home as well, like some of the others?

Child: No. They gave you a choice if you want to and I don't.

(Boy, age 11)

Further reflective of how the broader conditions of children's lives impinged upon their attitudes towards In Harmony, another theme commonly addressed by participants concerned the meanings accessible through music and music-related activity. In discussing this matter, children typically attended both to the qualities of the sounds they could produce using classical instruments and the ways these intersected, or not, with their wider musical enthusiasms. Children therefore detailed some of the ways they had attempted to incorporate instrument playing into creative musical activities of their own devising:

I'm aiming for to, like, make up a tune that sounds right, so I can play for my mum and my Dad and my little brother my tune that I just made up

(Girl, age 8) 
[Sometimes] we [interviewee and friends] just bring all our instruments and go around to one of the houses and get our instruments and play...[but] normally go on my computer, put some music on and go along [play along] in the tune that's being sung.

(Boy, age 8)

In many other cases however, the meanings accessible through classical music were positioned as lacking desirable qualities (e.g., "just instrumental" or "just music", as in devoid of meaningful lyrical or visual dimensions) and opportunities for meaning making were thereby seen as correspondingly limited:

I [would] like [to play] pop and rock when I get better, because it's got singing to it and everything, and the other one [classical music] is just like music with instruments.

(Girl, age 10)

Cos I thought they [In Harmony] would use not soothing instruments but stuff like piano, drums, the ones that can actually get [a] beat in them.

(Boy, age 9)

For most participants, there was little sense in which classical music repertoire held appeal. Indeed, the press and sponsor framing of In Harmony - drawing liberally upon notions of classical music's inspirational or transcendent qualities - was usually turned on its head in children's accounts, as its "soothing" qualities (children also used the terms "calm" and "smooth") meant that it was typically also seen as "boring".

As the two foregoing interview excerpts suggest, the music associated with In Harmony was sharply contrasted with children's expressed interests in popular music. In this, their accounts often gave prominence to matters of image, 'look', style or appearance, song lyrics and their perceived meanings, domestic technologies (TVs, laptop computers and tablet devices), the involvement of co-present family members, as well as activities such as dancing and singing along to pop songs. In describing the array of activities and experiences bound up with popular music, it was evident that many of these were either of a self-directed nature or else co-produced with peers or family members. In light of such abiding interests, it was easy to understand why the significantly different kinds of aesthetic experience and musical practice bound up with In Harmony presented challenges to many children at the level of perceived relevance and intrinsic motivation. Indeed, in respect of their musical passions, children's accounts contrasted sharply with the ways that press articles - in employing metaphors such as 'musical desert' and suggesting that children had yet to 'discover' music - framed the pre-existing cultural appetites of In Harmony's target communities.

A final key theme to emerge prominently across children's accounts concerned questions of ease/difficulty. Interestingly, children's attitudes towards the ease of orchestral instrument learning commonly correlated with the ways they spoke in relation to some of the themes detailed above. That is, where individual children described a relative lack of motivation and family validation vis-à-vis In Harmony, perceived its obligatory nature as oppressive and expressed an overwhelming preference for activities bound up with popular music, classical instrument playing/learning was often described in terms of the (unwelcome) challenges it presented:

Researcher: So how are you finding it, learning and playing your instrument?

Child: I don't like it... because I keep getting it wrong

(Girl, age 7) 
Researcher: Which do you prefer, singing or violin?

Child: $\quad$ Singing, because you don't have to do it for a long time. If you

have to do violin for a long time it starts to hurt your arm

(Girl, age 8)

Conversely, the tendency was for children who benefitted from greater family support and validation in their In Harmony activities welcomed the directive nature of In Harmony sessions and described lower levels of enthusiasm for popular music, to find their instrument playing/learning more amenable and satisfying:

I like to play my trumpet a lot...I've been playing for nearly about two years...I

like orchestra the best cos it's probably the easier

(Boy, age 10)

The music I prefer is things we learn at school. They tell you what to do and give clear instructions. You can just do it like that [clicks fingers].

(Girl, age 10)

Although such perspectives tended to be in the minority amongst the children interviewed, matters of ease or, inversely, of challenge nonetheless appeared crucial in influencing many children's overall attitudes towards their participation, however positive or negative these ultimately were:

Orchestra [practice], I don't like that, it's [it lasts] for ages, one hour.

(Boy, Year 5)

It's hard [playing violin], I like playing it quite a bit, but it's hard...[some] people

like doing things that they've already done cos it's easier. I like a challenge.

(Boy, age 8)

While the theme of 'challenge' resonates with both the 'discipline' and 'hard work' endorsed within press coverage, children views clearly problematise the assumption that this aspect of In Harmony should be seen as an asset rather than a potential disincentive to children's engagement.

\section{Discussion}

As the foregoing analyses have indicated, there is some overlap in the dimensions of In Harmony granted salience within the three sets of accounts considered. The strongest similarities can be seen in press and policy framing of In Harmony and especially in terms of their shared adherence to a 'transformation' frame. There were some nuanced differences here however, in that whereas press commentators tended to lay their emphasis on the civilising, redemptive power of Western art music practices and their potential to bring about 'transformation' at the individual level, the policy documents foregrounded In Harmony's envisaged role as an economically efficient agent of 'community change' and 'regeneration' (as engendered through a transformation in individuals). At no point do either the policy documents or press commentators acknowledge the need for, or desirability of 'transformation' in terms of the social structural iniquities which generate the deprivation characterising those communities (Stevenson, 2019). 
In Harmony's framing in both press articles and policy documents does, however, stand at considerable variance to the interpretations and understandings offered up by most participating children. The 'discipline' and 'rigour' attributed to the initiative, for instance - framed in terms of meritocratic opportunities for moral redemption within dominant accounts - translated into unwelcome or excessive challenge for many participants. Similarly, the 'spiritual poverty' linked to deprived communities' cultural abjection within press commentary contrasted markedly with the rich array of valued (popular) music-related activities detailed in children's accounts. In addition to such differences, numerous concerns wholly omitted from dominant accounts could be seen to bring meaningful, deleterious implications for participants. For instance, while the press corpus frames technical musical achievements as indicative of 'success' (both of El Sistema and In Harmony), practically no mention is made anywhere of matters such as creativity, expression or identity, despite numerous participants lamenting their absence from In Harmony (and, indeed, their widely acknowledged centrality to contemporary musical cultures - see, e.g. Frith, 1996; Toynbee, 2003). Similarly, in seeking to position In Harmony as an appropriate cultural intervention into host communities, press accounts frame them as either devoid of musical culture or else as characterised by cultural abjection. Problematically, such framing wholly obscures the pre-existing musical enthusiasms, understandings and practices which appeared influential upon many participants' limited interest in and commitment to In Harmony.

Stepping back from the specific differences between press, policy and participant accounts, it might be observed that the vehemence with which In Harmony is promoted by some of its 'transformation' frame sponsors - especially within the press commentary - served to both establish unrealistically high expectations of the initiative and means that the potential value of a reasoned reflection upon the factors at work in delivering variably (un-)successful outcomes is at best overlooked and at worst supressed. In other words, on the basis of the participant accounts gathered, it seems clear that gaining an understanding of the extent to which the initiative variably delivers benefits to different children requires both an analysis attentive to the conditions (such as parental validation or pre-existing musical interests) conducive to more or less successful outcomes and an appreciation of the fact that value might, in fact, accrue in the ways participants come to act in relation to those conditions (e.g. in enhancing their relationships with parents). However, the extent to which press commentators, programme representatives and policy makers embraced both the El Sistema model and its associated 'social uplift' narrative appears to have set limits on the programme's ability to effectively adapt and respond to the conditions and concerns relevant to its young stakeholders.

\section{Conclusion}

The phrase 'too big to fail', as employed in this article's title, is one usually applied to financial institutions seen as so fundamental to the functioning of capitalist economies that governments simply cannot condone their failure. In a similar way, my use of this expression in relation to In Harmony points towards the beliefs and interests at stake in the dominant framing of this initiative as a 'success', the broader symbolic role of In Harmony and the associated marginalisation of those participant voices suggestive of its weaknesses.

The beliefs and interests at stake include those of In Harmony sponsors and concern their apparent faith in the inherent value of classical music and its amenability to the "rhetoric of positive transformation" (Belfiore, 2011, p. 27) which has come to dominate debates about the 'effects' of art and culture within both cultural policy and educational fields. To these interests we might add those of the arts institutions keen to retain public funding and legitimacy through their association with a project designed to 'reach out' to and 'transform' those living in deprived communities. Each of these constituencies stands to benefit, in particular ways, from the image of In Harmony as a 'success'.

As noted above, it is also important to consider policies and initiatives qua 'politics' in relation to questions of 'success'/'failure' (McConnell, 2010). On this point, In Harmony might be said - at one level - to have contributed to successive governments' reputations by supplying a media-friendly story of 'transformation' which ostensibly signals a concern to improve the lives of deprived children through a mode of cultural practice usually seen as the preserve of more privileged groups. At a broader symbolic level, when In Harmony's prominent profile and positive framing are viewed in relation to the policies affecting music education provision in England since 2011, the initiative's role in deflecting attention from deepening funding cuts and accelerated privatisation and marketisation (Spruce \& Philpott, 2015) might also be acknowledged. 
In light of the interests served by promulgating an image of In Harmony as a 'success', it might be suggested that the relative inattention granted to its young participants' interpretations - apparent from not only media accounts but also official evaluations $^{20}$ - is less an unfortunate oversight than a core constituent of Sistema-inspired models. The need for analysts of cultural participation policy to bring a heightened awareness to matters of 'politics' and symbolism in relation to questions of 'failure'/'success' would therefore seem clear. 


\section{Acknowledgements}

The author would like to thank the participating schools and children for dedicating their time to the research project from which aspects of this article draw. He would also like to thank the other members of the research team, Prof John Street (University of East Anglia) and Dr Tom Phillips (University of East Anglia), as well as Prof Anna Robinson-Pant (University of East Anglia) for advice regarding data collection.

\section{Funding Acknowledgement}

Some of the research discussed in this article was sponsored by the UK Arts and Humanities Research Council (Grant AH/ L004909/1). 


\section{References}

Alemán, X., Duryea, S., Guerra, N., McEwan, P., Muñoz, R., Stampini, M., \& Williamson, A. (2016). The effects of musical training on child development: A randomized trial of El Sistema in Venezuela. Prevention Science, 18, 865-878. https://doi.org/10.1007/s11121-016-0727-3

Allan, J., Moran, N., Duffy, C., \& Loening, G. (2010). Knowledge exchange with Sistema Scotland. Journal of Education Policy, 25(3), 335-347. https://doi.org/10.1080/02680931003646196

Arnold, M. (1869/1994), Culture and anarchy. Samuel Lipman (Ed.). New Haven and London: Yale University Press.

Arts Council England (ACE). (n.d.). 'In Harmony'. Retrieved from https://www.artscouncil.org.uk/music-education-programmes/harmony

Arts Council England (ACE). (2010). Achieving great art for everyone, a strategic framework for the arts. Retrieved from https://www.artscouncil.org.uk/sites/default/files/download-file/Great_art_and_culture_for_everyone.pdf

Asthana, A., \& Thorpe, V. (2008, June 15). Free instruments for poor children. The Observer.

Badham, B., \& Wade, H. (2005). Hear by right: Standards for the active involvement of children and young people. London: The National Youth Agency/Local Government Association.

Baker, G. (2014). El Sistema: Orchestrating Venezuela's youth. Oxford: OUP

Baker, G. (2019). El Sistema, "The Venezuelan Musical Miracle": The construction of a global myth. Latin American Music Review, 39(2), 160-193. https://doi.org/10.7560/LAMR39202

Belfiore, E. (2002). Art as a means towards alleviating social exclusion: Does it really work? A critique of instrumental cultural policies and social impact studies in the UK. International Journal of Cultural Policy, 8(1), 91 - 106. https://doi. org/10.1080/102866302900324658

Belfiore, E. (2009). On bullshit in cultural policy practice and research: Notes from the British case. International Journal of Cultural Policy, 15(3), 343-359. https://doi.org/10.1080/10286630902806080

Belfiore, E. (2011). The "transformative power" of the arts: History of an idea. In J. Sefton-Green, P. Thomson, K. Jones \& L. Bresler (Eds.), The Routledge International Handbook of Creative Learning (pp. 27-35). Abingdon: Routledge

Belfiore, E. (2016). Cultural policy research in the real world: curating "impact", facilitating "enlightenment". Cultural Trends, 25(3), 205-216. https://doi.org/10.1080/09548963.2016.1204050

Belfiore, E., \& Bennett, O. (2007). Rethinking the social impact of the arts. International Journal of Cultural Policy, 13(2), 135- 151. https://doi.org/10.1080/10286630701342741

Belfiore, E. \& Bennett, O. (2008). The social impact of the arts: An intellectual history. London: Palgrave Macmillan.

Bennett, O. (1995). Cultural policy in the United Kingdom: Collapsing rationales and the end of a tradition. The European Journal of Cultural Policy, 2(4), 199-216. https://doi.org/10.1080/10286639509357982

Blackmore, L. (2007, August 17). The street children saved by music. The Independent.

Bourdieu, P. (1984). Distinction: A social critique of the judgement of taste. London, Routledge.

Bovens, M., \& 't Hart, P. (1996). Understanding policy fiascoes. New Brunswick, NJ: Transaction.

Bull, A. (2016). El Sistema as a bourgeois social project: Class, gender, and Victorian values. Action, Criticism, and Theory for Music Education, 15(1), 120-153. http://act.maydaygroup.org/articles/Bull 15 1.pdf

Bull, A. (2019). Class, control, and classical music. New York, NY: Oxford University Press.

Burns, S., \& Bewick, P. (2011). In Harmony Liverpool Interim Report: Year 2. Liverpool Philharmonic/DfE. https://www.liverpoolphil.com/media/190714/in-harmony-liverpool-evaluation-update-year-2.pdf

Cassidy, S. (2008, June 21). Orchestral manoeuvre to give poorest children hope. The Independent.

Cox, G. (1993). A history of music education in England, 1872-1928. Aldershot: Scholar Press.

Creech, A., Gonzalez-Moreno, P., Lorenzino, L., \& Waitman, G. (2013). El Sistema and Sistema-Inspired Programmes: A literature review of research, evaluation, and critical debates. Sistema Global: San Diego, California. https: $/ /$ sistemaglobal.org/wp-content/uploads/2016/03/ESv2_full_version_Final.pdf

Crossick, G., \& Kaszynska, P. (2016). Understanding the value of arts \& culture: The AHRC Cultural Value Project. Swindon: Arts and Humanities Research Council.

Department for Children, Schools and Families (DCSF). (2008). Young people leading change. London: Department for Children Schools and Families. 
Department for Education (DfE). (2011 a). Music education in England - A review by Darren Henley. London: DFE \& DCMS. https://assets.publishing.service.gov.uk/government/uploads/system/uploads/attachment_data/file/175432/DFE00011-2011.pdf

Department for Education (DFE). (2011 b). Music education in England - The Government response to Darren Henley's review of music education. London: DfE. https://assets.publishing.service.gov.uk/government/uploads/system/uploads/ attachment data/file/177100/DFE-00012-2011.pdf

Department for Education (DFE). (2011 c). A national plan for music education. London: DfE.https://assets.publishing.service. gov.uk/government/uploads/system/uploads/attachment data/file/180973/DFE-00086-2011.pdf

Department for Education (DFE). (2016). Thousands of children to benefit from music and arts investment, November 18: https://www.gov.uk/government/news/thousands-of-children-to-benefit-from-music-and-arts-investment

Dobson, N. (2016). Hatching plans: Pedagogy and discourse within an El Sistema-inspired program. Action, Criticism, and Theory for Music Education, 15(1), 89-119. http://act.maydaygroup.org/articles/Dobson 15_1.pdf

Dommett, E. (2011, November 25). Music hits all the right notes. The Times Educational Supplement.

Dromey, C., \& Haferkorn, J. (Eds). (2018). The classical music industry. Abingdon, Oxon: Routledge.

Edelmann, M. (1964). The symbolic uses of politics. Urbana: University of Illinois Press.

Edelman, M. (1988). Constructing the political spectacle. Chicago, IL: University of Chicago Press.

Ehrlich, C. (1985). The music profession in Britain since the eighteenth century: A social history. Oxford: Clarendon.

Entman, R. M. (1993). Framing: Toward clarification of a fractured paradigm. Journal of Communication, 43(4), $51-58$.

Fairclough, N. (2013). Critical discourse analysis and critical policy studies. Critical Policy Studies, 7(2), 177-197. https:// doi.org/10.1080/19460171.2013.798239

Fink, R. (2016). Resurrection symphony: El Sistema as ideology in Venezuela and Los Angeles. Action, Criticism, and Theory for Music Education, 15(1), 33-57. http://act.maydaygroup.org/articles/Fink 15 1.pdf

Fischer, F. (2003). Reframing public policy: Discursive politics and deliberative practices. Oxford: Oxford University Press.

Frith, S. (1996). Performing rites: On the value of popular music. Cambridge: Harvard University Press.

Gamson, W. A., \& Lasch, K. E. (1983). The political culture of social welfare policy. In S. E. Spiro \& E. Yuchtman-Yaar (Eds.), Evaluating the welfare state: Social and political perspectives (pp. 397-415). San Diego, CA: Academic Press.

Gamson, W. A., \& Modigliani, A. (1989). Media discourse and public opinion on nuclear power: A constructionist approach. American Journal of Sociology, 95(1), 1-37.

Gee, C. B. (2002). The "use and abuse" of arts advocacy and consequences for music education. Arts Education Policy Review, 103(4), 3-21. https://doi.org/10.1080/10632910209600294

Gee, C. B. (2004). Spirit, mind, and body: Arts education the redeemer. In E. Eisner \& M. Day (Eds.), Handbook of research and policy in art education (pp.115-194). Mahwah, NJ: Laurence Erlbaum.

Gibson, L., \& Edwards, D. (2016). Facilitated participation: Cultural value, risk and the agency of young people in care. Cultural Trends, 25(3), 194-204. https://doi.org/10.1080/09548963.2016.1204049

Gitlin, T. (1980). The whole world is watching. Berkeley and Los Angeles: University of California Press.

Gove, M. (2012, September 29) Letter: Every child can discover music. The Guardian.Hallam, R., \& Hanke, M. (2012). In Harmony Sistema England: A coherent music education. ISME Conference 2012 Special Interest Group Submission. Available: http://www.dickhallam.co.uk/resources/In\%20Harmony\%20Sistema\%20England\%20A\%20Coherent\%20Music\%20Education\%20ISME\%202012.pdf

Hallam, S. (2010, September 24). Music must take centre stage in primaries or we risk striking a bum note for society. The Times Educational Supplement.

Hallam, S., Rogers, L., \& Creech, A. (2011). Interim evaluation of 'In Harmony'. London: University of London, Institute of Education. Unpublished report.

Hallam, S., \& Burns, S. (2017). Research into support for musical progression for young people from In Harmony programmes and other disadvantaged communities. Leeds, UK: Opera North/Arts Council England. https://www. artscouncil.org.uk/sites/default/files/download-file/In harmony Final report.pdf

Hallam, S., \& Burns, S. (2018). Progression in instrumental music making for learners from disadvantaged communities: A literature review. Leeds, UK: Opera North/Arts Council England. https://www.artscouncil.org.uk/sites/default/files/ download-file/In harmony Literature review.pdf

Hewitt, S. (2009). Discourse analysis and public policy research. Centre for Rural Economy Discussion Paper Series, 24, $1-16$. 
Higgins, C. (2006, November 24). Land of hope and glory. The Guardian.

Higgins, C. (2009, April 24). Notes from Venezuela: The ideal of El Sistema is shared in Britain: it needs defending with the spirit Abreu's musicians show. The Guardian.

Hough, S. (2010, May 18). Music unlocks the key to their souls. The Daily Telegraph.

Johnson, J. (2002). Who needs classical music? Cultural choice and musical value. Oxford: Oxford University Press.

Kaszynska, P. (2015). Capturing the vanishing point: Subjective experiences and cultural value. Cultural Trends, 24(3), 256-266.

Khan, R. (2019). Researchers, bureaucrats and the lifeworlds of cultural policy. International Journal of Cultural Policy, 25(4), 528-540. https://doi.org/10.1080/10286632.2017.1341498

Lakoff, G., \& Johnson, M. (1980). Metaphors we live by. Chicago: University of Chicago Press.

Lloyd Webber, J. (2009a, April 26). Music for all: POINTS. The Sunday Times.

Lloyd Webber, J. (2009b, December 23). The music that cuts crime and saves lives. The Daily Telegraph.

Lloyd Webber, J. (2011 a, August 14). Letters: Fruits of harmony. The Sunday Times.

Lloyd Webber, J. (2011 b, November 25). Julian Lloyd Webber: On the children enriched by music. The Telegraph.

Lloyd Webber, J. (2013, August 28). I'm doing a Dudamel over here. The Independent.

Lloyd Webber, J. (2015, December 19). £278m concert hall is a classic mistake. The Times.

Local Government Group. (2011). Valuing young voices, strengthening democracy. London: Local Government Group.

Logan, O. (2015). Hand in glove: El Sistema and neoliberal research. https://www.researchgate.net/publication/287202150

Logan, O. (2016). Lifting the veil: A realist critique of Sistema's upwardly mobile path. Action, Criticism, and Theory for Music Education, 15(1), 58-88. http://act.maydaygroup.org/articles/Logan 15 1.pdf

Lord, P. Sharp, C., Harland, J., Mehta, P., \& White, R. (2016). Evaluation of In Harmony: final report. Slough: National Foundation for Educational Research (NFER). https://www.nfer.ac.uk/publications/ACII04/ACII04.pdf

Machin, D., \& Mayr, A. (2012). How to do critical discourse analysis. A multimodal introduction. London: Sage.

McConnell, A. (2010). Policy success, policy failure and grey areas in-between. Journal of Public Policy, 30(3), $345-362$. https://doi.org/10.1017/S0143814X10000152

McConnell, A. (2015). What is policy failure? A primer to help navigate the maze. Public Policy and Administration, 30(3-4), 221 -242. https://doi.org/10.1177/0952076714565416

McGuigan, J. (2001). Three discourses of cultural policy. In N. Stevenson (Ed.), Culture and Citizenship (pp.124- 137). London: Sage.

Merli, P. (2002). Evaluating the social impact of participation in arts activities. International Journal of Cultural Policy, 8(1), 107-118. https://doi.org/10.1080/10286630290032477

Miles, A., \& Sullivan, A. (2012). Understanding participation in culture and sport: Mixing methods, reordering knowledges. Cultural Trends, 21 (4), 311-324. https://doi.org/10.1080/09548963.2012.726795

Miles, A., \& Gibson, L. (2016). Everyday participation and cultural value. Cultural Trends, 25(3), 151 - 157. https://doi: 10.10 80/09548963.2016.1204043.

Millington, B. (2007, 20 August). An epic journey from slum to Shostakovich; Proms 2007. London Evening Standard.

Millington, B. (2018, April 5). José Antonio Abreu obituary. The Guardian.

Mota, G., Baker, G., Ilari, B., O'Neill, S., \& Senyshyn, Y. (2016). Social inclusion and non-formal music learning: In the shadow of Venezuela's El Sistema. In R. Wright, C. Beynon \& B. Younker (Eds.), 21 st century music education: Informal learning and non-Formal teaching (pp. 38-54). Waterloo, Ontario: Canadian Music Educators' Association.

Pan, Z., \& Kosicki, G.M. (1993). Framing analysis: An approach to news discourse. Political Communication, 10, 55-75.

Pritchard, S. (2007, August 26). Caracas about them. The Observer.

Rimmer, M. (2017). Music, middle childhood and agency: The value of an interactional-relational approach. Childhood: A Global Journal of Child Research, 24(4), 559-573. https://doi.org/10.1177/0907568217711741

Rimmer, M. (2018). Harmony or Discord? Understanding children's valuations of a Sistema-inspired initiative. British Journal of Music Education, 35(1), 43-55.

Rimmer, M., Street, J., \& Phillips, T. (2014). Understanding the cultural value of In Harmony-Sistema England. Arts \& Humanities Research Council/University of East Anglia. https://veaeprints.uea.ac.uk/id/eprint/50664/4/Rimmer et al_2014_Understanding_the_Cultural_Value_of_In_Harmony_Sistema_England_final_.pdf 
Ritchie, M. (2009, June 12). Melody makers. The Times Educational Supplement.

Roberts, A. (2009, April 20). Anything Venezuela can do, Lambeth can do much better. The Evening Standard.

Romer, C. (2016, 24 November). No link between In Harmony participation and attainment. Arts Professional.

Savage, J. (2018). Music education for all. Forum, 60(1), 111 - 122. http://doi.org/10.15730/forum.2018.60.1.111

Scruton, R. (2007). Culture counts. New York, NY: Encounter Books.

Selwood, S. (2002). The politics of data collection: Gathering, analysing and using data about the subsidised cultural sector in England'. Cultural Trends, 12(47), 14-84. https://doi.org/10.1080/09548960209390330

Shave, N. (2011, February 9). Bittersweet symphonies. The Guardian.

Shieh, E. (2015). Relationship, rescue, and culture: How El Sistema might work. In C. Benedict, P. Schmidt, G. Spruce \& P. Woodford (Eds.), The Oxford Handbook of Social Justice in Music Education (pp. 567-581). New York: Oxford University Press.

Shiner, L. (2001). The invention of art. Chicago: University of Chicago Press.

Sistema England. (2015). About. Retrieved from http://www.sistemaengland.org.uk/about/

Sistema Global. (2015). About Sistema Global. Retrieved from http://sistemaglobal.org/about/

Spruce, G. (2013). "The National Music Plan" and the taming of English music education. Arts Education Policy Review, 114(3), 112-118. https://doi.org/10.1080/10632913.2013.803412

Spruce, G. (2017). The power of discourse: Reclaiming social justice from and for music education. Education 3-13, 45(6), 720-733. https://doi.org/10.1080/03004279.2017.1347127

Spruce, G., \& Philpott, C. (2015, April 25). What is a socially just approach to music education? [Conference presentation]. El Sistema and the Alternatives: Social Action through Music in Critical Perspective, University of London.

Stevenson, D. (2016). Understanding the problem of cultural non-participation: Discursive structures, articulatory practice and cultural domination [Unpublished doctoral dissertation]. Queen Margaret University, Musselburgh. https://eresearch. qmu.ac.uk/bitstream/handle/20.500.12289/7339/2198.pdf? sequence=1 \&isAllowed=y

Stevenson, D. (2019). The cultural non-participant: Critical logics and discursive subject identities. Arts and the Market, 9(1), 50-64.

Stevenson, D., Balling, G., \& Kann-Rasmussen, N. (2015). Cultural participation in Europe: Shared problem or shared problematisation? International Journal of Cultural Policy, 23(1), 89-106. http://dx.doi.org/10.1080/10286632.2015. 1043290

Stolz, B. A. (2007). Interpreting the US human trafficking debate through the lens of symbolic politics. Law \& Policy, 29(3), $311-38$.

The Times. (2018, March 26). Obituary: José Antonio Abreu. The Times.

Toynbee, J. (2003). Music, culture and creativity. In M. Clayton, R. Middleton \& T. Herbert (Eds.), The cultural study of music (pp. 102-112). New York, NY: Routledge.

UK Government. (2008, June 20). Unprecedented investment in music education has the power to change children's lives. M2 PressWIRE.

Van Gorp, B. (2007). The constructionist approach to framing: Bringing culture back in. Journal of Communication, 57(1), $60-78$.

Vulliamy, E. (2010, October 3). How could classical music reach into the lives of some of Britain's poorest kids and give them the confidence to dream of a different life? Here's how.... The Observer.

Waterton, E. (2010). Politics, policy and the discourses of heritage in Britain. London: Palgrave.

Weber, W. (1975). Music and the middle class: The social structure of concert life in London, Paris and Vienna between 1830 and 1848. New York: Holmes and Meier.

White, H. (2014, December 18). Access to music should be every child's basic right, says singer songwriter. The Guardian.

Yanow, D. (2000). Conducting interpretive policy analysis. Newbury Park, CA: Sage. 


\section{Endnotes}

1 A symbolic politics framework assumes that the general public's perception of and/or reaction to political acts is more important than their substance (see, e.g. Edelman, 1964; Stolz, 2007).

2

\section{See: https://www.artscouncil.org.uk/music-education-programmes/harmony}

Amongst which figure the Royal Liverpool Philharmonic Orchestra, Opera North and The Sage Gateshead (home to the Royal Northern Sinfonia).

These include bodies such as Royal Birmingham Conservatoire, Manchester Camerata, the University of Nottingham Department of Music as well as local music services.

'Sistema England' is the name of the charity set up by Julian Lloyd Webber in 2010 to help raise funds for the three In Harmony pilot programmes.

Database search terms combining 'In Harmony' with both 'music' and 'Sistema' were used and the corpus was subsequently filtered to remove duplicate and irrelevant results. Most press pieces related to the period of In Harmony's initial establishment and expansion (2008 to 2012). Sixty six of the articles found mentioned 'In Harmony' just once, while fifty one mentioned it on two or more occasions.

The research team comprised the article author together with Prof John Street and Dr Tom Phillips.

Lloyd Webber wrote a total of 10 feature-length articles as well as a number of letters published in national press between 2007 and 2015 .

For instance, both Tom Service and Ivan Hewett have presented programmes on the classical music-oriented radio station BBC Radio 3, while Marshall Marcus features on both television and radio as a judge on classical music-oriented BBC Young Musician of the Year.

This unpublished report appears to have fed into policy-making processes relevant to In Harmony (see discussion of Henley's review (under subheading 'Analysis 2: Policy documents')).

This term refers to characteristics of the associated subject (in this instance, 'families allowing failure') that, by implication, attach to the principal subject (i.e. participants' families).

For reasons that are not made clear in the report to which these percentages appear to relate, they concern just 26 case study pupils (Burns \& Bewick, 2011, p. 18) - from a total school roll of 104 pupils - selected for inclusion in an evaluation of In Harmony Liverpool. The evaluation was led by a former employee of the project's lead organisation, the Royal Liverpool Philharmonic.

Belfiore's (2016) comments regarding the potency of statistics within cultural policy debates are apposite here insofar as the statistical data employed within press coverage of In Harmony appears to provide another instance of how quantitative data might be "quoted for years without its original source and its reliability ever being verified" (Belfiore 2016, p. 212).

Henley, former managing director of classical music radio station 'Classic FM', had 'sat on the In Harmony Steering Group since 2008' (DfE, 2011 a, p. 44). At the time of writing he is Chief Executive of ACE.

Under the coalition and subsequent Conservative governments, the policy of 'academisation' has seen increasing numbers of previously state-funded schools move away from direct local authority control to becoming quasi-independent. This meant that 'academy' schools have been at liberty to buy music-related services from a range of providers. 
16 Music education 'hubs' are regional groups of organisations comprised of local authority departments, schools, other hubs, arts organisations and community or voluntary organisations. Having been first proposed in Henley's review (DfE, 2011 a), they subsequently replaced local authority music services as core providers of schools music services in England.

17 The pupil premium is a grant given by the government to schools in England for 'disadvantaged pupils' (as determined by their looked-after status or receipt of free school meals).

18 This term refers to the effort to persuade through an over-abundance of particular words and synonyms (Machin \& Mayr, 2012).

19 Gibson and Edwards define these as "programmes that aim to effect individuals' social, economic, mental, physical, educational and/or emotional state or status and where the individuals enlisted are deemed to be in need or amenable to 'betterment' through such participation" (2016, p. 195).

20 See Rimmer (2018), especially pp. 44-45. 